\title{
KETERBUKAAN INFORMASI UU PASAR MODAL MENCIPTAKAN ASYMMETRIC INFORMATION DAN SEMI STRONG FORM ${ }^{1}$
}

\author{
Suwinto Johan ${ }^{1,2^{*}}$, Ariawan ${ }^{2}$ \\ ${ }^{1}$ Fakultas Bisnis, Universitas President \\ Jababeka Education Park, Jl. Ki Hajar Dewantara, Kota Jababeka, Cikarang Baru, Bekasi 17550 \\ ${ }^{2}$ Program Magister Ilmu Hukum, Fakultas Hukum, Universitas Tarumanagara \\ Jl. Letjen S. Parman No.1, Jakarta 11440 \\ suwintojohan@gmail.com
}

\begin{abstract}
A stock exchange is classified as an efficient if the information is open and known to all parties equally. Law No. 8 of 1995 requires the disclosure of material information with a maximum period of two working days after the material information is occured. This study aims to examine the relationship between the obligation to disclose material information and an efficient market based on the Efficient Market Hypothesis. This study uses a normative juridical method. This study found that the maximum reporting obligation of two working days will result in delays in information for capital market players. The capital market will not be an efficient market. An inefficient capital market will not make optimal returns. Regulations regarding reporting material information need to be revised.
\end{abstract}

Keywords: Efficient Market Hypothesis; Public Information; Capital Market Law.

\begin{abstract}
Abstrak
Sebuah pasar modal digolongkan sebagai pasar yang efisien atau akurat jika informasi yang ada di bursa tersebut terbuka dan diketahui oleh semua pelaku secara merata. Undang Undang No. 8 Tahun 1995 mewajibkan keterbukaan informasi material dengan jangka waktu maksimal 2 hari kerja setelah adanya informasi yang material. Penelitian ini bertujuan untuk meneliti keterkaitan antara kewajiban keterbukaan informasi material dengan mewujudkan pasar modal yang efisien berdasarkan Efficient Market Hypothesis. Penelitian ini menggunakan metode yuridis normatif. Penelitian ini menemukan bahwa kewajiban pelaporan maksimal 2 hari kerja akan mengakibatkan keterlambatan informasi bagi pelaku pasar modal. Pasar modal yang tidak efisien tidak akan membuat pengembalian yang optimal. Pengaturan mengenai pelaporan informasi yang material perlu dirubah.
\end{abstract}

Kata Kunci: Efficient Market Hypothesis; Keterbukaan Informasi; Undang-Undang Pasar Modal.

\footnotetext{
${ }^{1}$ Artikel hasil penelitian mandiri yang dilakukan penulis di Program Magister Ilmu Hukum Fakultas Hukum Universitas Tarumanagara pada tahun 2020.
} 


\section{A. Pendahuluan}

Kebanyakan dari kita pernah mendengar cerita penampakan burung bangau dari bulan. Suatu hari, Bulan menceritakan kepada seorang anak kecil bahwa akan ada penampakan burung bangau pada besok malam. Bulan meminta anak kecil tersebut jangan menceritakan kepada siapapun jika ingin melihat Burung Bangau. Setelah itu, anak kecil tersebut menceritakan kepada kakaknya di rumah, karena mereka adalah saudara kandung. Kakaknya menceritakan kepada ibunya, karena hubungan anak dan ibu. Kemudian ibunya menceritakan kepada adiknya, adiknya menceritakan kepada suaminya. Besok malam, seluruh warga kampung berkumpul ingin melihat penampakan Burung Bangau dari Bulan. Penyebaran informasi semakin cepat beredar dengan perkembangan teknologi saat ini. Penyebaran informasi dengan menggunakan sosial media seperti social messaging telah merevolusi penyebaran informasi.

Cara melakukan transaksi di pasar modal telah berubah dengan adanya aplikasi yang ada di mobile device. Mobile device seperti laptop, handphone, dan gadget lainnya. Dengan cara bertransaksi yang mudah, penyebaran informasi juga dengan sangat mudah diperoleh. Seseorang cukup menjadi pengikut beberapa sosial media, maka dia akan memperoleh informasi.

Penyebaran informasi bisa melalui forum diskusi yang ada pada aplikasi transaksi pasar modal, melalui grup-grup pembahasan pasar modal di sosial media, maupun melalui posting pada sosial media seperti Facebook dan Instagram. Semua investor pasar modal mengharapkan adanya keuntungan atau return daripada investasi. Salah satu tindakan untuk memperoleh keuntungan adalah memiliki informasi terlebih dahulu. Keunggulan informasi akan mengakibatkan investor yang memiliki informasi untuk mengambil keputusan dalam investasi.

Seorang investor yang memiliki informasi mengenai kinerja perusahaan dan informasi ini belum dipublikasi. Investor tersebut dapat menjual sahamnya dan terhindar daripada kerugian. Investor dapat memperoleh informasi melalui sosial media seperti grup-grup diskusi saham di aplikasi transaksi maupun membaca posting di sosial media. Seorang investor memperoleh informasi mengenai rencana kerja perusahaan yang ekspansif. Informasi ini belum diketahui oleh pasar, sehingga harga sahamnya masih rendah. Informasi tersebut dilaporkan oleh manajemen perusahaan terbuka ke regulator dan menjadi informasi publik. Investor tersebut membeli pada harga yang rendah dan menjual sahamnya. Investor tersebut akan memperoleh keuntungan.

Jika ada informasi yang tidak terbuka untuk luar, di mana pihak internal perusahaan mengetahui dan melakukan transaksi atas keunggulan informasi ini. Transaksi ini menghasilkan keuntungan bagi pemilik informasi. Maka transaksi ini disebut sebagai insider trading. Pada Pasal 95 Undang Undang No. 8 Tahun 1995 tentang Pasar Modal (yang selanjutnya disebut UU Pasar Modal), menegaskan bahwa orang dalam dari emiten atau perusahaan publik yang mempunyai informasi orang dalam dilarang melakukan pembelian atau penjualan atas efek daripada emiten atau perusahaan publik dimaksud; atau perusahaan lain yang melakukan transaksi dengan emiten atau perusahaan publik tersebut.

Informasi yang diatur di sini, adalah informasi orang dalam. Transaksi tidak hanya terkait dengan emiten atau perusahaan publik terkait, tetapi juga emiten atau perusahaan publik yang terkait dengan transaksi yang dilakukan. Selain orang dalam, perusahaan efek yang memiliki informasi, juga dilarang melakukan transaksi. Pasal 96 UU Pasar Modal juga telah menegaskan bahwa perusahaan efek yang memiliki informasi orang dalam mengenai emiten atau perusahaan publik dilarang melakukan transaksi efek emiten atau perusahaan publik tersebut. Informasi yang material wajib diketahui oleh seluruh pelaku pasar modal. 
Undang-Undang Pasar Modal ini mengatur kewajiban bagi perusahaan yang akan melakukan penawaran umum atau perusahaan yang dikategorikan atau memenuhi persyaratan sebagai perusahaan publik untuk menyampaikan informasi kepada umum, mengenai keadaan kegiatan usahanya, segi keuangan, manajemen, produksi maupun hal yang berkaitan dengan kegiatan usahanya kepada masyarakat. Informasi ini mempunyai arti yang sangat penting bagi masyarakat atau investor sebagai bahan pertimbangan untuk melakukan keputusan investasi.

UU Pasar Modal telah mengatur mengenai keterbukaan informasi. Informasi atau Fakta Material adalah informasi atau fakta penting dan relevan mengenai peristiwa, kejadian, atau fakta yang dapat mempengaruhi harga Efek pada Bursa Efek dan atau keputusan pemodal, calon pemodal, atau pihak lain yang berkepentingan atas informasi atau fakta tersebut. Jika perusahaan terbuka tidak membuka informasi material maka akan dikenakan sanksi (Agusta, 2020).

Keterbukaan atau transparansi merupakan prinsip dari Good Corporate Governance yang diakomodasikan ke dalam peraturan perundang-undangan di bidang pasar modal, di mana pada sektor pasar modal keterbukaan adalah mutlak (Herlina, 2018). Pasar modal didefinisikan sebagai pasar atau tempat pertemuan bagi penjual dan pembeli yang memperdagangkan sekuritas. Aktivitas pasar modal begitu rumit, dibutuhkan instrumen hukum yang mengaturnya sehingga pasar berjalan secara teratur dan adil bagi semua pihak (Suardana, Mahendrawati, \& Astiti, 2020).

Berdasarkan penjelasan Pasal 7 UU Pasar Modal, informasi atau fakta material, adalah antara lain informasi mengenai: penggabungan usaha, pengambilalihan, peleburan usaha atau pembentukan usaha patungan; pemecahan saham atau pembagian dividen; pendapatan dan dividen yang luar biasa sifatnya; perolehan atau kehilangan kontrak penting; produk atau penemuan baru yang berarti; perubahan tahun buku perusahaan; dan perubahan dalam pengendalian atau perubahan penting dalam manajemen; sepanjang informasi tersebut dapat mempengaruhi harga efek dan atau keputusan pemodal, calon pemodal, atau pihak lain yang berkepentingan atas informasi atau fakta tersebut.

Pada Pasal 86 UU Pasar Modal, Emiten yang pernyataan pendaftarannya telah menjadi efektif atau perusahaan publik wajib menyampaikan laporan secara berkala kepada Otoritas Jasa Keuangan (OJK) dan mengumumkan laporan kepada masyarakat; dan menyampaikan laporan kepada OJK dan mengumumkan tentang peristiwa material yang dapat mempengaruhi harga efek selambat-lambatnya pada akhir hari kerja ke-2 (kedua) setelah terjadinya peristiwa tersebut.

Jika informasi tidak disampaikan kepada masyarakat, maka berdasarkan Pasal 81 UU Pasar Modal, setiap pihak yang menawarkan atau menjual efek dengan menggunakan Prospektus atau dengan cara lain, baik tertulis maupun lisan, yang memuat informasi yang tidak benar tentang fakta material atau tidak memuat informasi tentang fakta material dan pihak tersebut mengetahui atau sepatutnya mengetahui mengenai hal tersebut wajib bertanggung jawab atas kerugian yang timbul akibat perbuatan dimaksud. Prinsip keterbukaan dalam pasar modal berarti bahwa emiten maupun profesi penunjang pasar modal wajib memberikan informasi mengenai fakta materill secara tetap dan benar serta jujur sehingga nantinya akan berpengaruh terhadap keputusan pemodal untuk menanamkan modalnya di pasar modal (Wisudawan, 2015).

Keterbukaan adalah suatu prinsip transparansi yang dilakukan perusahaan melalui suatu jasa penilaian dalam penawaran saham perdana dan merupakan sebab hal mengambil keputusan bagi investor sangat penting untuk membeli saham, efek dari itu menjadikan investor mau membeli atau tidak dari suatu perusahaan go public berdasarkan atas laporan yang disampaikan oleh perusahaan 
jasa penilai dari hasil penilaiannya terhadap harta perusahaan tersebut yang dilampirkan dalam dokumen propektus secara transparan (Indra, Pratiwi, \& Perdana, 2019).

\section{Efficient Market Hypothesis}

dikemukakan oleh Eugene Fama pada tahun 1970 (Fama, 1970). Fama mengategorikan bentuk pasar modal menjadi 3 jenis yakni weak, semi strong dan strong form. Weak form merupakan bentuk pasar modal dimana informasi berdasarkan hanya data histori. Teori efisiensi pasar telah menjadi acuan kajian yang mendapat perhatian luas selama tiga dasawarsa terakhir (Gumanti \& Utami, 2002).

Strong form merupakan bentuk pasar modal dengan informasi yang dimiliki oleh pihak-pihak tertentu dan menjadi terbuka untuk umum. Pasar efisien bentuk kuat menyatakan bahwa harga efek yang terjadi mencerminkan semua informasi yang ada, baik informasi publik (public information) maupun informasi pribadi (private information). Semua informasi terbuka untuk umum. Jadi, dalam hal ini, bentuk kuat mencakup semua informasi historis yang relevan dan juga informasi yang ada di publik yang relevan termasuk laporan keuangan dan lainnya, di samping juga informasi yang hanya diketahui oleh beberapa pihak tertentu, misalnya manajemen perusahaan, dewan direksi, dan kreditor. Semua informasi yang diketahui adalah milik publik. Para peneliti sepertinya sepakat untuk menyebut bahwa pengujian terhadap bentuk kuat hipotesis pasar efisien sering dikaitkan dengan keberhasilan dalam penggunaan akses monopolistik terhadap informasi oleh pelaku pasar tertentu.
Efficient Market Hypothesis berhubungan dengan efisiensi atau kecepatan penyebaran informasi yang dimiliki oleh investor umum dari transparansi informasi terbatas menjadi informasi yang terbuka untuk umum (Santoso \& Ikhsan, 2019).

Informasi yang tidak merata atas sebuah transaksi antara para pihak disebut asymmetric information. Asymmetric information adalah kondisi dimana suatu pihak memiliki informasi yang lebih banyak dari pihak lain. Manajemen perusahaan tahu lebih banyak tentang perusahaan dibanding investor di pasar modal (Hidayah \& Ferawati, 2013). Informasi Asimetris (Asymmetric Information) adalah suatu kondisi dimana ada satu pihak memiliki informasi yang lebih baik daripada pihak yang lain (Hidayah \& Ferawati, 2013). Dalam hal keterbukaan informasi material, maka adanya pihak tertentu yang memiliki informasi terlebih dahulu, sebelum diketahui oleh publik dalam waktu 2 hari kerja. Sehingga, pasar modal menimbulkan asymmetric information. Asymmetric information ini berpeluang menimbulkan keuntungan bagi pihak yang memiliki informasi terlebih dahulu dibandingkan dengan pihak lainnya.

Dalam hal pinjam memimjam, Asymmetric information adalah perbedaan informasi yang didapatkan antara pihak bank syariah dan nasabah, dalam hal ini nasabah lebih banyak mengetahui tentang keadaan usaha yang dijalankannya berbanding terbalik dengan pihak bank syariah sehingga kemungkinan terjadinya penyimpangan sangat besar (Lubis, 2016; Sarono, 2019).

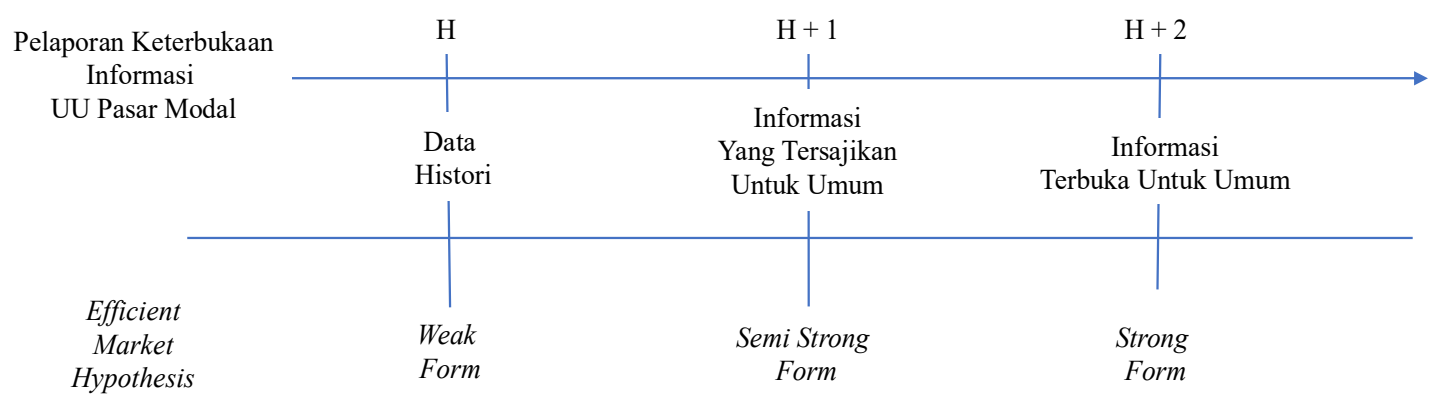

Gambar 1. Kerangka Pemikiran UU Pasar Modal vs Efficient Market Hypothesis Sumber: Hasil Penelitian 
Kewajiban melakukan pelaporan informasi material adalah maksimal 2 hari kerja sejak terjadinya transaksi atau kejadian $($ Hari $\mathrm{H}+2)$. Sebelum pelaporan atau antara waktu transaksi sampai dengan waktu kejadian, ada kemungkinan timbulnya asymmetric information sehingga menimbulkan abnormal market activities atau unusual market activities. Sehingga kondisi pasar modal di Indonesia akan tidak efisien selama waktu sebelum pemberitahuan informasi material kepada otoritas. Pasar modal pada negara berkembang tidak efisien dalam arti fluktuasi harga selama ini tidak memiliki pola yang unik (Hallunovi, 2018).

Pada hari $\mathrm{H}$ telah terjadi transaksi, akan tetapi kewajiban pelaporan pada $\mathrm{H}+2$ yakni dua hari setelah hari kejadian. Antara hari $\mathrm{H}$ sampai dengan $\mathrm{H}+2$, informasi material telah berpotensi menjadi informasi yang terbuka untuk umum. Hal ini digambarkan pada Gambar 1. Jika informasi tersebut dapat dikendalikan sejak hari $\mathrm{H}$ hingga $\mathrm{H}+2$, maka pasar modal jenis ini disebut sebagai pasar modal yang memiliki strong form menurut teori Efficient Market Hypotheis (Fama, 1970). Informasi dengan mudah disebar dan adanya pihak yang memperoleh keuntungan dari penyebaran informasi yang asymetris, disebut pasar modal weak form.

Pasar weak form memperoleh informasi hanya data histori. Informasi material akan terbuka untuk publik jika dibuka, kalau informasi tidak terbuka, maka informasi yang tersedia adalah informasi-informasi historical yang ada. Informasi historical merupakan informasi yang telah ada dan terbuka untuk umum. Utami (2018) menyimpulkan bahwa bursa saham Asia, termasuk Indonesia, efisiensi pasar modal berbentuk lemah (Utami, 2018).

Pasar semi strong form memperoleh informasi yang tersajikan untuk umum seperti laporan keuangan. Informasi yang tersedia adalah informasi yang disajikan untuk umum. Informasi yang ada di laporan keuangan tersedia untuk umum ketika publikasi di koran.
Pasar modal Indonesia berbentuk semi strong form. Pengujian ini didasarkan pada abnormal return dan cumulative abnormal return sebelum dan sesudah tanggal pengumuman penerbitan warrant di Bursa Efek Indonesia (Nelmida, 2020). Pasar modal di Indonesia berbentuk semi kuat dalam efisiensi pasar (Artini, Darmayanti, \& Sidiartha, 2020; Saputra, Purbawangsa, \& Artini, 2017). Penelitian-penelitian menunjukkan bahwa event study telah diketahui oleh pasar dan pasar tidak memberikan reaksi yang signifikan ketika pengumuman diberikan. Penelitianpenelitian dijelaskan pada tabel 1 .

Tabel 1.

Penelitian mengenai Bentuk Pasar

\begin{tabular}{|c|c|c|}
\hline No. & $\begin{array}{c}\text { Bentuk Pasar Modal } \\
\text { di Indonesia }\end{array}$ & Penelitian \\
\hline 1. & Weak Form & Utami (2018) \\
\hline 2. & Semi Strong Form & $\begin{array}{l}\text { Nelmida } \\
\text { Artini et al }(2020) \\
\text { Saputra et al. }\end{array}$ \\
\hline 3. & Strong Form & Tidak Ditemukan \\
\hline
\end{tabular}

Pasar strong form menunjukkan bahwa semua informasi yang ada terbuka untuk umum, tidak ada informasi yang tertutup. Pada pasar berbentuk kuat, semua informasi terbuka untuk umum. Pada saat kejadian atau kebijakan diambil, informasi akan segera diketahui oleh umum. Semua pelaku pasar modal akan mengetahui dengan segera semua informasi mengenai kondisi perusahaan. Semua pihak memiliki posisi informasi yang dalam mengambil keputusan investasi.

Penelitian mengenai peraturan perundang-undangan pasar modal telah banyak dilakukan. Penelitian mengenai bentuk-bentuk pasar modal berdasarkan teori ekonomi dan teori efisiensi pasar juga telah banyak. Penelitian mengenai keterkaitan peraturan perundang-undangan dengan teori pasar modal masih sangat jarang ditemukan.

Penelitian bertujuan untuk mengkombinasikan keilmuan teori pasar modal yakni Efficient Market Hypothesis 
teori oleh Fama dengan praktik pasar modal didasarkan pada peraturan perundangundangan. Penelitian ini akan memberikan gambaran praktik di bidang ekonomi, khususnya pasar modal dengan peraturan perundang-undangan. Hasil penelitian ini akan memberikan gambaran kebijakan yang akan diambil oleh regulator.

Berdasarkan latar belakang yang telah diuraikan, maka perumusan masalah penelitian ini adalah: Pertama, apakah kewajiban pelaporan keterbukaan informasi maksimal dua hari kerja menimbulkan asymmetric information dan terciptanya pasar modal yang tidak efisien? Kedua, bagaimanakah pelaporan keterbukaan informasi agar mendukung terciptanya pasar modal yang efisien?

Hasil penelitian ini akan memberikan masukan kepada regulator dan investor dalam mengambil keputusan investasi. Regulator dapat menentukan batas waktu pelaporan informasi material bagi perusahaan terbuka. Penelitian akan mendukung bentuk pasar modal Indonesia yang efisien dengan bentuk pasar yang kuat. Pengaturan kewajiban pelaporan informasi material sangat diperlukan untuk memberikan keadilan informasi kepada semua pelaku pasar modal.

\section{B. Metode Penelitian}

Berlandaskan latar belakang dan perumusan masalah maka metode yang dipergunakan dalam penelitian ini adalah metode penelitian hukum normatif atau penelitian hukum kepustakaan. Penelitian ini dilakukan dengan cara meneliti bahan-bahan pustaka atau bahan sekunder. Penelitian hukum normatif atau kepustakaan meliputi penelitian terhadap asas-asas dan normanorma hukum, penelitian terhadap sistematika hukum, penelitian terhadap taraf sinkronisasi horizontal dan vertikal antar peraturan perundang-undangan. Dalam hukum normatif, penelitian ini menggunakan pendekatan peraturan perundang-undangan (statute approach), melakukan penelaah terhadap semua undang-undang dan regulasi yang terkait.
Pendekatan peraturan perundang-undangan adalah pendekatan dengan menggunakan legislasi dan regulasi. Dengan metode ini, penelitian menganalisis regulasi, mengidentifikasi dan menyesuaikan dengan regulasi terkait.

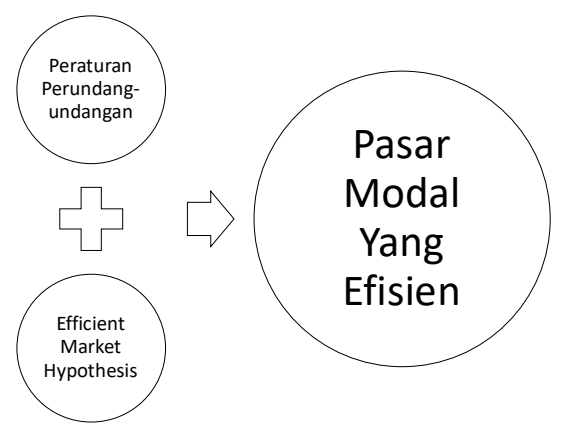

Gambar 2. Kerangka Pemikiran Sumber: Hasil Penelitian

Bahan penelitian hukum normatif yakni bahan hukum primer, bahan hukum sekunder dan bahan hukum tersier atau penunjang. Bahan hukum primer yang dipergunakan dalam penelitian ini UUD Republik Indonesia Tahun 1945 dan peraturan terkait lainnya. Bahan hukum sekunder yang digunakan antara lain: literatur-literatur berupa jurnal-jurnal hukum, teori-teori hukum, buku ilmiah yang berkaitan dengan judul penelitian, hasil simposium/seminar, dan artikel karangan ilmiah. Bahan hukum tersier adalah bahan yang menjelaskan bahan hukum primer dan hukum sekunder. Kerangka pemikiran digambarkan pada Gambar 2. Kombinasi teori pasar modal dan penyesuaian peraturan perundang-undangan diharapkan dapat menghasilkan pasar modal yang efisien.

\section{Hasil dan Pembahasan}

\section{Kewajiban Pelaporan Keterbukaan Informasi Maksimal Pada Hari ke-2 Menimbulkan Asymmetric Information dan Terciptanya Pasar Modal yang Tidak Efisien}

Pelaporan atas transaksi material wajib dilakukan pada hari kerja ke-2 setelah transaksi. Sejak terjadinya transaksi ataupun sebelum transaksi terjadi, informasi 
mengenai transaksi berpotensi telah beredar. Hal ini menunjukkan pasar modal di Indonesia berbentuk semi strong form sesuai dengan hasil penelitian yang telah ada (Artini et al., 2020; Nelmida, 2020; Saputra et al., 2017; Widyasari, Suffa, Amalia, \& Praswati, 2018).

Salah satu contoh informasi material adalah Standard Chartered Bank mau melepas saham Bank Permata, diberitakan pada tanggal 26 Februari 2019 (Septiadi, 2020). Bank Mandiri menampik isu akuisisi dan harga saham Bank Permata turun pada tanggal 20 Februari 2019 (Dewi, 2020). Rumor akuisisi Bank Permata oleh Bank Mandiri kembali menaikkan harga saham kedua bank pada tanggal 1 April 2019 (CNN Indonesia, 2019). Bank Mandiri menyatakan sedang menyelesaikan proses uji tuntas atas transaksi pembelian saham PT. Bank Permata pada tanggal 9 April 2019 (Nurcaya, 2020). Bank Mandiri batal mengakuisisi Bank Permata diumumkan pada tanggal 27 Mei 2019. Bank Permata diakuisisi oleh Bangkok Bank pada bulan Mei 2020 (Ulya, 2020). Sebelumnya di akhir tahun 2019, Bangkok Bank mengumumkan akan mengakuisisi Bank Permata (Dolorosa, 2015).

Saham Bank Permata mengalami perubahan yang signifikan sesuai dengan rumor yang diberitakan. Pergerakan saham dari awal tahun 2019 mencapai Rp. 630/saham, mencapai Rp. 1150/saham pada masa ada rumor akuisisi oleh Bank Mandiri. Kemudian Bank Mandiri batal melakukan akuisisi menjadi Rp. 790/saham. Jika investor memperoleh informasi dan membeli pada tanggal 2 Januari 2019 dan menjual pada tanggal 19 Februari 2019. Investor tersebut akan memperoleh keuntungan sebesar $82,50 \%$ dalam waktu satu bulan lebih.

Pada tanggal 9 April 2019, Bank Mandiri mengumumkan akan melakukan uji tuntas terhadap Bank Permata. Jika investor membeli pada saat itu, maka harga saham adalah Rp. 1000/lembar saham. Kemudian investor mengetahui pembatalan transaksi, maka investor akan mengalami kerugian sebesar $21 \%$. Jika investor membeli pada saat Bank Mandiri membatalkan transaksi pada harga Rp. 790/lembar, kemudian menjualnya pada saat pengumuman Bangkok Bank akuisisi Bank Permata. Investor tersebut akan memperoleh keuntungan sebesar 60\%. Gambaran ini menunjukkan bahwa informasi memegang peranan penting. Keuntungan atau kerugian investor sangat tergantung pada informasi yang diperoleh.

Transaksi lainnya yang disebabkan oleh insider trading adalah rencana akuisisi Bank Danamon oleh DBS. Kejadian ini menjadi kasus insider trading (Dolorosa, 2015). Transaksi ini mengakibatkan mantan kepala UBS dijatuhkan sanksi oleh Otoritas Moneter Singapore (Gideon, 2015). Praktik Insider Trading adalah merupakan praktik kecurangan, sebab prinsip keterbukaan dibagikan kepada publik adalah informasi yang bersifat materil atau fakta materil dan relevan mengenai peristiwa, kejadian, atau fakta yang dapat mempengaruhi harga efek pada Bursa Efek dan/atau keputusan pemodal, calon pemodal atau pihak yang berkepentingan atas informasi atau fakta tersebut (Wisudawan, Ismail, \& Budiarto, 2018).

Transaksi pengambilalihan, peleburan maupun penggabungan, maka transaksi tersebut berpotensi diketahui oleh publik atau diketahui pihak terlibat seperti penasehat transaksi (advisory), penasehat hukum, akuntan publik, penasehat pajak, dan lainnya. Pemegang saham akan mengetahui transaksi ini pada saat diadakannya Rapat Umum Pemegang Saham (RUPS) atau pada hari $\mathrm{H}$ sesuai dengan Pasal 89 UU No. 40 Tahun 2007 tentang Perseroan Terbatas. Perbankan selaku kreditur mengetahui transaksi yang akan diadakan, karena transaksi pengambilalihan memerlukan persetujuan daripada kreditur (sebelum hari $\mathrm{H}$ ). Kreditur mengetahui transaksi yang akan terjadi. 


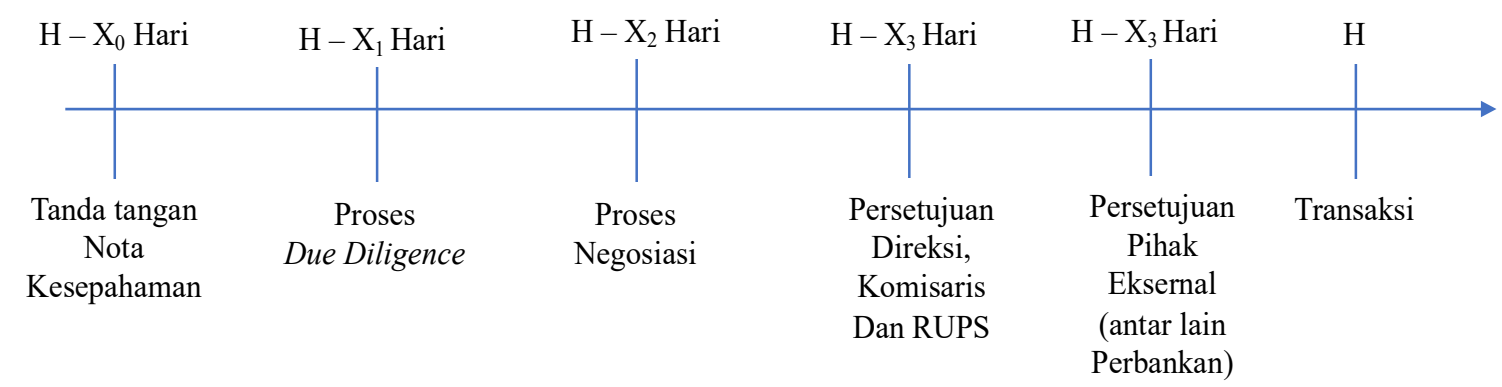

Gambar 3. Proses Pengambilalihan

Sumber: Hasil Penelitian

Jumlah pihak yang akan mengetahui transaksi pengambilialihan digambarkan pada Gambar 3. Publik baru akan mengetahui transaksi ini setelah adanya pelaporan. Dengan demikian, publik akan mengalami keterlambatan dalam memperoleh informasi karena diperbolehkannya pelaporan $\mathrm{H}+2$ sesuai dengan Pasal 86 UU Pasar Modal.

Pasar modal Indonesia akan mencapai strong from pada akhir hari kedua, ketika informasi terbuka untuk publik, setelah pelaporan transaksi yang material. Akan tetapi, dengan waktu 2 hari kerja ini, jika ada kebocoran informasi maka, akan terjadi asymmetric information hingga terjadinya abnormal market activities digambarkan pada Gambar 3.

Abnormal market activities merupakan sebuah pergerakan harga saham yang tidak normal atau tidak biasa dibandingkan dengan kondisi normal atau histori. Kondisi normal ini digambarkan pada periode sebelum $\mathrm{H}$ atau $\mathrm{H}-(\mathrm{H}$ minus). Kriteria abnormal return dibedakan ke dalam 3 kelompok yakni perbandingan pergerakan saham yang terjadi dibandingkan dengan pergerakan saham saat sebelumnya, dengan pergerakan saham perusahaan sejenis yang ada di pasar, dibandingkan dengan ekspektasi perubahan harga saham yang terjadi.

Sedangkan abnormal activities adalah pergerakan saham yang tidak normal pada masa $\mathrm{H}$ hingga $\mathrm{H}+2$. Pada periode ini, harga saham mengalami kenaikan dibeli oleh kelompok yang memiliki informasi disebut kelompok $\mathrm{X}$, karena transaksi $\mathrm{H}$ akan memberikan kondisi yang menguntungkan untuk perusahaan. Setelah pengumuman pada $\mathrm{H}+2$, kelompok $\mathrm{X}$ menjual sahamnya, masyarakat umum mulai membeli saham perusahaan karena mengetahui adanya transaksi. Hal ini digambarkan pada gambar 4. Kelompok X mengambil keuntungan.

Dengan demikian, informasi pada pasar modal adalah asymmetric information. Ada pihak yang memperoleh informasi terlebih dahulu 2 hari dibandingkan dengan pihak lainnya. Sehingga pasar modal Indonesia adalah semi strong. Penyampaian informasi pada hari kedua dari kejadian atau peristiwa material telah menimbulkan tidak terjadi abnormal return. Pelaporan ini mengikuti ketentuan pada UU Pasar Modal. Pada saat hari $\mathrm{H}$ hingga hari $\mathrm{H}$ ditambah 1 hari, informasi telah tersebar, pelaporan resmi dilakukan pada hari $\mathrm{H}$ ditambah 2 hari kerja. Dengan pengujian secara ilmiah, maka pengujian ini menyimpulkan bahwa kondisi pasar normal atau tidak terjadi abnormal return pada saat keterbukaan informasi kepada publik. Hal ini digambarkan pada gambar 4.

Berdasarkan analisis tersebut, penelitian menyimpulkan pasar modal Indonesia berbentuk semi strong form disebabkan oleh peraturan perundang-undangan yang mengatur pelaporan dilakukan maksimal 2 hari kerja. Untuk membuat pasar modal yang lebih efisien berbentuk strong form, maka keterbukaan informasi dipersingkat menjadi 1 hari kerja atau mengumumkan kepada publik maksimal pada hari berikutnya. 


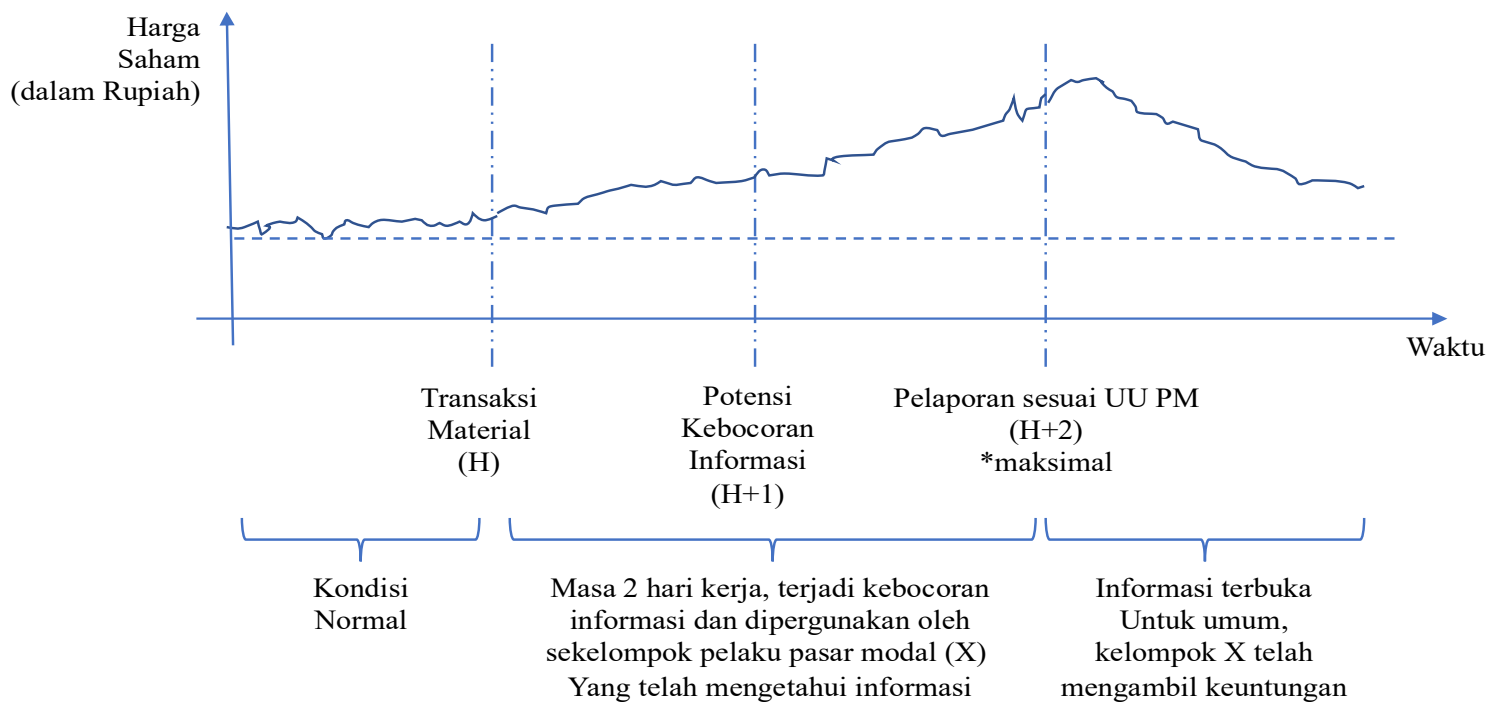

Gambar 4. Abnormal Return Efficient Market Hypothesis

Sumber: Hasil Penelitian

\section{Pelaporan Keterbukaan Informasi agar Mendukung Terciptanya Pasar Modal yang Efisien}

Pasar modal yang efisien adalah pasar modal yang berbentuk strong form. Informasi menyangkut emiten atau perusahaan publik merupakan informasi yang diketahui oleh semua pelaku pasar modal. Asymmetric information juga tidak boleh terjadi karena akses informasi oleh pihak tertentu. Akibat dari ini, maka ada pihak yang memperoleh keuntungan atau meminimumkan kerugian akibat memiliki kemampuan akses informasi ini.

Kewajiban pelaporan informasi material perlu direvisi dengan melakukan pelaporan pada saat kejadian atau maksimal 1 hari setelah kejadian. Jika diperlukan adalah melakukan pre-notification. Perusahaan atau emiten dapat mengumumkan rencana sebuah kejadian atau mungkin sebuah informasi yang akan terjadi. Pre-notification adalah pemberitahuan atas rencana sebuah kejadian atau keputusan usaha yang memiliki dampak material.

Hal ini juga terkait transaksi corporate action seperti penggabungan dan pengambilalihan sesuai dengan Pasal 29 Undang Undang No. 5 Tahun 1999 Tentang Larangan Prakek Monopoli dan Persaingan Usaha Tidak Sehat. Berdasarkan UU
Persaingan Usaha, tindakan pengambilalihan dilakukan secara post-notification. Pengungkapan secara pre-notification telah banyak terjadi pada transaksi merger dan akuisisi di beberapa negara. Pre-notification akan membuka informasi kepada semua pelaku pasar. Transaksi merger akuisisi dengan sistem pre-notification ada di China, Amerika Serikat, Singapore, Thailand, European Union (Johan, 2020).

Perlu dilakukan sinkronisasi antara UU Pasar Modal dengan UU terkait termasuk UU Nomor 40 Tahun 2007 tentang Perseroan Terbatas dan UU Nomor 5 Tahun 1999 tentang Larangan Praktek Monopoli dan Persaingan Usaha. Pelaporan keterbukaan informasi material harus memenuhi persyaratan bahwa informasi material diketahui oleh semua pihak secara terbuka. Tidak boleh ada pihak yang memiliki informasi yang tidak diketahui oleh pihak lainnya. Pelaporan informasi yang diatur dalam UU Pasar Modal, masih memakai pola pemikiran di tahun 1995, sedangkan penyebaran informasi telah berkembang pesat dengan bantuan teknologi, sehingga bentuk pelaporan informasi material perlu disesuaikan dengan perkembangan teknologi. Penyebaran informasi telah berkembang sangat pesat dan dalam hitungan detik, informasi bisa 
dengan mudah tersebar. Dengan pola ini, maka informasi pasar modal akan dengan cepat tersebar. Perubahan waktu kewajiban pelaporan informasi material akan membuat pasar modal Indonesia dapat memberikan informasi yang terbuka kepada semua pelaku pasar. Perubahan waktu pelaporan digambarkan pada Gambar 5.

Untuk mencapai tidak adanya asymmetric information atau keterbukaan informasi material untuk semua pihak, maka dapat dilakukan beberapa tindakan sebagai berikut ini:

1. pre-notification, semua pihak berhak mengetahui informasi yang sama lengkapnya. Pre-notification adalah pemberitahuan mengenai sebuah rencana kegiatan atau informasi yang akan dilakukan oleh perusahaan. Pemberitahuan ini dimaksudkan agar keterbukaan informasi dan menjadi transaksi yang lebih efisien (Johan, 2020). Dalam pre-notification ini, perusahaan wajib menyampaikan mengenai potensi transaksi bisa terjadi atau batal.

2. Pelaporan informasi harus dilakukan dengan segera, tidak harus menunggu paling lambat hari kerja ke-2. Perubahan kewajiban pelaporan informasi material dengan mengubah atau amendem terhadap UU Nomor 8 Tahun 1995 tentang Pasar Modal. Perubahan ini sejalan dengan perkembangan teknologi dan sistem pelaporan.

3. Otoritas melakukan pemeriksaan lebih intensif terhadap transaksi yang tidak normal. Pemantauan terhadap penyebaran informasi yang informal menjadi informasi resmi.

4. Bentuk pelaporan informasi material, perlu ditinjau kembali, apakah dilakukan dengan self reporting atau self publishing di website perusahaan tanpa perlu melalui otoritas terkait. Perusahaan melakukan selfpublishing di website perusahaan untuk informasi material.

5. Jika dalam kondisi tertentu, tetap ada pihak tertentu yang memiliki informasi, maka pihak tersebut harus taat pada kewajiban dalam menjaga informasi yang material. Jika adanya informasi yang tersebar, maka para pihak akan dikenakan sanksi. Pihakpihak yang karena posisi atau profesi memiliki informasi terlebih dahulu wajib disampaikan kepada regulator.

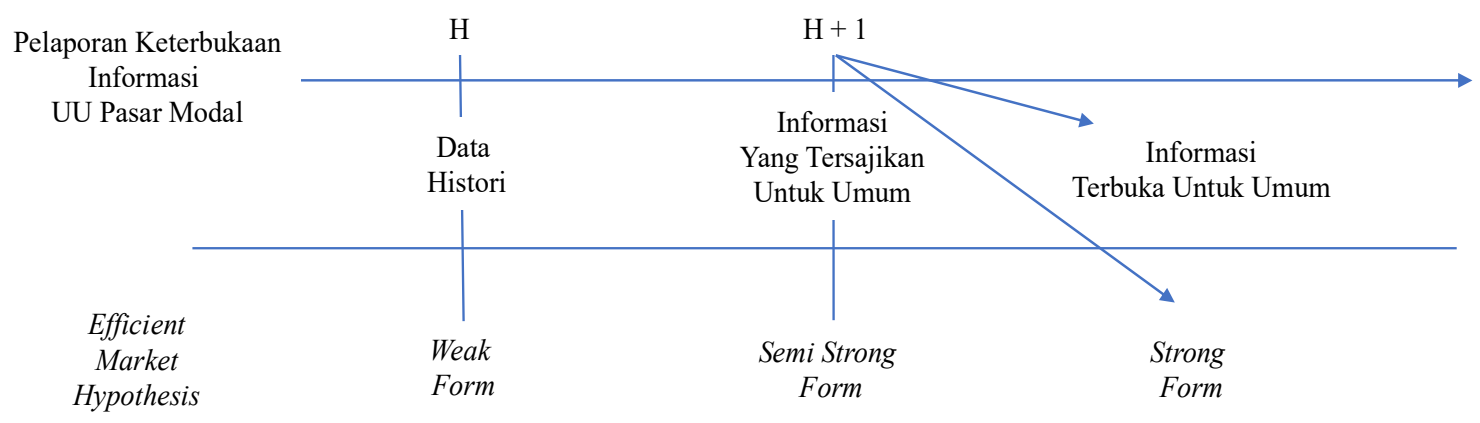

Gambar 5. Perubahan Waktu Pelaporan Informasi Material

Sumber: Hasil Penelitian 
Usaha-usaha tersebut dapat dilakukan untuk terciptanya pasar modal yang efisien berbentuk strong form dan tidak adanya asymmetric information. Pasar modal yang weak form atau semi strong form, akan menguntungkan sekelompok pelaku pasar. Pelaku pasar yang memilki akses, akan memperoleh keuntungan atau kerugian yang minimum.

Aktivitas-aktivitas tersebut merupakan solusi agar perubahan kebijakan penyampaian informasi material dari maksimal 2 hari kerja menjadi maksimal 1 hari. Sehingga hal yang perlu dilakukan adalah perubahan kewajiban penyampaian informasi material dalam UU PM.

Perubahan waktu ini sejalan dengan dukungan perkembangan teknologi yang semakin pesat seperti website perusahaan yang dapat dijangkau oleh semua pihak, sosial media perusahaan yang terbuka untuk semua pelaku pasar modal. Peraturan perundang-undangan Pasar Modal saat ini diundangkan pada tahun 1995. Pada tahun 1995, perkembangan teknologi tidak secepat dan sepesat saat ini. Sehingga perubahan ini menjadi hal yang lumrah dilakukan. Pada tahun 1995, belum ada transaksi saham atau obligasi dengan mempergunakan aplikasi yang ada di handphone maupun di laptop.

\section{Simpulan dan Saran}

Pasar modal yang efisien adalah pasar modal yang berbentuk strong form, informasi material diketahui oleh semua pelaku pasar modal atau tidak terjadinya asymmetric information. Pelaporan atau keterbukaan informasi paling lambat hari ke-2 kerja akan mengakibatkan potensi asymmetric information. Asymmetric information ini mengakibatkan keuntungan atau kerugian pada pihak tertentu dan mengakibatkan kerugian atau keuntungan pada pihak lainnya. Kewajiban pelaporan ini mengakibatkan timbulnya asymmetric information and membuat pasar modal Indonesia berbentuk semi strong form. Perubahan terhadap sistem pelaporan terutama jangka waktu dan cara penyampaian pelaporan perlu ditinjau kembali. Peninjauan ini mempertimbangkan perkembangan teknologi dalam penyebaran informasi. Peninjauan ini sejalan dengan transaksi pasar modal telah dilakukan secara elektronik, UU Pasar Modal perlu disesuaikan dengan UU ITE.

Penelitian ini menyarankan kepada regulator untuk meninjau kembali kewajiban melaporkan atau mempublikasi informasi material dalam waktu 2 hari setelah kejadian. Informasi telah beredar dan diketahui oleh pelaku pasar. Untuk membentuk pasar modal yang efisien, maka pelaporan dapat dilakukan dalam waktu yang lebih singkat. Dengan pembatasan waktu dua hari kerja, pelaku pasar akan mendengarkan rumor yang beredar daripada informasi yang resmi. Informasi resmi akan mengalami keterlambatan daripada rumor atau informasi informal.

Penelitian dapat dikembangkan dengan melakukan studi komparatif terhadap regulasi yang ada pada negara lain sejalan dengan perkembangan teknologi komunikasi. Penelitian lainnya dapat dikembangkan dengan menguji penyebaran informasi lainnya melalui sosial media baik melalui diskusi grup, diskusi aplikasi transaksi dalam jaringan maupun posting yang ada pada sosial media lainnya. Hasil penelitian akan dapat menambah pemikiran mengenai kecepatan penyebaran informasi yang terjadi di jaringan sosial media.

\section{DAFTAR PUSTAKA}

Agusta, H. (2020). Pertanggungjawaban KHPM Dalam Proses IPO Jika Terdapat Fakta Material Yang Tidak Diungkap. Masalah-Masalah Hukum, 49(1), 4860.

http://doi.org/https://doi.org/10.14710/ mmh.49.1.2020.48-60

Artini, L. G. S., Darmayanti, N. P. A., \& Sidiartha, G. M. (2020). Pengujian Anomali Size Effect di Pasar Modal Indonesia. Matrik: Jurnal Manajemen, Strategi Bisnis Dan Kewirausahaan, 14(2), 158-168. 
CNN Indonesia. (2019). Rumor Akuisisi Kerek Saham Bank Mandiri dan Bank Permata.

Dewi, H. K. (2020). Mandiri Menapik Isu Akuisis Saham Bank Permata Terjun Bebas. Retrieved October 12, 2020, from

https://investasi.kontan.co.id/news/man diri-menampik-isu-akuisisi-sahambank-permata-bnli-terjun-bebas

Dolorosa, G. N. (2015). Kasus Insider Trading: BEI Panggil UBS Indonesia.

Fama, E. (1970). Efficient Capital Markets: A Review Of Theory And Empirial Work. The Journal of Finance, 25(2), 383-417.

Gideon, A. (2015). Otoritas Singapura Beri Sanksi Mantan Kepala UBS Indonesia.

Gumanti, T. A., \& Utami, E. S. (2002). Bentuk Pasar Efisiensi dan Pengujiannya. Jurnal Akuntansi Dan Keuangan, 4(1), 54-68.

Hallunovi, A. (2018). The Efficient Market Hypothesis in Developing Countries: Indonesia. Xournals: Academic Journal of Accounting and Finances, 1(1), 1-6.

Herlina, E. (2018). Implementasi Prinsip Transparansi Sebagai Salah Satu Prinsip-Prinsip Good Corporate Governance dalam Pasar Modal. Pemuliaan Hukum, 1(1), 1-14.

Hidayah, N., \& Ferawati, D. (2013). Analisis Pengaruh Ukuran Perusahaan Dan Net Profit Margin Terhadap Struktur Modal Pada Perusahaan Industri Semen Yang Go Public di Bursa Efek Indonesia. Quality: Jurnal Manajemen Dan Akuntasi, 2(12), 103119.

Indra, P., Pratiwi, T., \& Perdana, I. (2019). Aspek Hukum Prinsip Keterbukaan Perdagangan Saham Oleh Profesi Penunjang Pasar Modal. Jurnal Pionir LPPM, 5(4), 197-212.
Johan, S. (2020). Implikasi Yuridis Post Merger Notification oleh Pelaku Usaha Indonesia. Dialogica Iuridica Jurnal Hukum Bisnis Dan Investasi, 12(1), 6480.

Lubis, A. (2016). Agency Problem Dalam Penerapan Pembiayaan Akad Mudharabah Pada Perbankan Syariah. Alqalam, 33(1), 46-62.

Nelmida. (2020). Is Indonesia Stock Exchange Semi-Strong Form Efficiency? Jurnal Manajemen, 24(2), 313.

Nurcaya, I. A. (2020). Bank Mandiri Mulai Negosiasi Pembelian Saham Bank Permata.

Santoso, E. B., \& Ikhsan, M. (2019). Efficient Market Hypothesis in Indonesia Stock Exchange. In Annual International Conference on Accounting Research (AICAR 2019) 127 (pp. 5153).

Saputra, I. K. G., Purbawangsa, I. . A., \& Artini, S. G. L. (2017). Reaksi Pasar di Sekitar Peristiwa Kenaikan Harga BBM Pada Return Saham IDX30 di Bursa Efek Indonesia. E-Jurnal Ekonomi Dan Bisnis Universitas Udayana, 3(6), 963 990.

Sarono, A. (2019). Analisis Problem Pembiayaan Mudharabah Serta Solusinya. Diponegoro Private Law Review, 4(1), 401-409.

Septiadi, A. (2020). Standard Chartered Mau Melepas Saham Ini Jawaban Bank Permata.

Suardana, I. N., Mahendrawati, N. L., \& Astiti, N. G. K. S. (2020). Perlindungan Hukum Terhadap Investor Berdasarkan Prinsip Keterbukaan oleh Emiten di Pasar Modal. Jurnal Analogi Hukum, 2(2), 182-186.

Ulya, F. N. (2020). Sah, Bangkok Bank Resmi Akuisisi Bank Permata diunduh dari pada tanggal. 
Utami, A. T. (2018). Efisiensi Pasar Bentuk Lemah Pada Pasar Modal Indonesia, Malaysia dan Korea Selatan Periode Krisis Ekonomi Global 2008. Jurnal Inspirasi Bisnis Dan Manajemen, 2(2), 101.

http://doi.org/https://doi.org/10.33603/ji bm.v2i2.1476

Widyasari, T. N., Suffa, I. F., Amalia, N., \& Praswati, A. N. (2018). Analisis Reaksi Pasar Modal Atas Peristiwa Kebijakan Amnesti Pajak 2016 (Studi Efisiensi Pasar Modal Indonesia). Jurnal Administrasi Bisnis, 6(2), 137.
Wisudawan, I. G. A. (2015). Penerapan Sanksi Hukum Terhadap Profesi Penunjang Pasar Modal Atas Informasi yang Tidak Benar dan Menyesatkan dalam Pembuatan Prospektus Menurut Undang-Undang No 8 Tahun 1995 Tentang Pasar Modal. Jurnal Jatiswara, 3(1), 45-70.

Wisudawan, I. G. A., Ismail, H. J. S., \& Budiarto, A. (2018). Tanggung Jawab Hukum Emitan Terhadap Praktek Insider Trading di Pasar Modal Menurut Undang Undang No. 8 Tahun 1995. Jurnal Unmas Mataram, 12(2), 22-31. 